\title{
Auditor's Professional Specialization Role in Reducing the Potential Negative Effects of Mandatory Audit-Firm Rotation on Audit Quality
}

Mohamed A Elshawarby*

Department of Accounting, Higher Institute for Computers and Management Information Systems, Cairo, Egypt

\begin{abstract}
This study aims at investigating the effect of professional specialization on audit quality. It examines the relation between professional specialization and the potential negative effects of MAFR on audit quality. Actually, the questionnaire was distributed among auditors and professor of accounting in Egypt confirmed hypothesis: there are statistically significant differences among the categories of inquisitors, the impact of the professional specialization of auditors on audit client choices when the audit client apply the mandatory rotation policy and there is a significant relation between auditor professional specialization and mandatory audit-firm rotation. There is a significant association between auditor professional specialization and reducing the potential adverse effects of mandatory audit-firm rotation. The study has reached auditor rotation can lead to improved audit quality, but when the incoming auditor is the auditor's professional specialization have significant impact on the potential negative effects of mandatory audit-firm rotation on audit quality.
\end{abstract}

Keywords: Audit quality; Auditor professional specialization; Mandatory audit-firm rotation

\section{Introduction}

This study examines the impact of professional specialization on the relationship between on the auditor rotation-audit quality relationship in Egypt; the professional specialization provides additional insights into the auditor rotation-audit quality relationship to reducing the potential negative effects of mandatory audit rotation on the audit quality. This study is concerned with the Egyptian environment in respect of the relation between mandatory audit-firm rotation and the audit quality and how this relation is affected by auditor professional specialization and It's clear how important is studying and measuring how the auditor professional specialization can reduce the potential negative effects of mandatory audit-firm rotation on audit quality.

Therefore this research is expected to provide first time evidenceaccording to the researcher's knowledge - on the association between auditors' specializations and potential negative effects of mandatory audit-firm rotation on audit quality. Auditors' specialization refers to auditors' being specialized in auditing specific industries.

This is probably because audit firms which are professional specialized invest time and financial resources in developing personnel and technology in specific industries, which should lead to better understanding of the clients' business, operations, and risks, and hence to improved audit quality [1].

As a result, auditors working in audit firms which are professional specialists have more opportunities to develop expertise than those working in non-specialist firms [2] and are also less likely to be misled by management representations [1]. Auditor professional specialization is also a proxy for the incentives for auditors to protect their reputation and minimize litigation risk [3].

Auditors who are professional specialists probably have incentives to protect their reputation because they have more to lose from poor audit quality in terms of losing future revenue streams and fee premiums. Thus, they have greater incentives than have non specialists to make high quality audits, be more independent, so as to avoid damaging this reputation [4].

This study is expected to provide evidence for Egyptian companies when choosing the external auditors; the potential negative effects of mandatory audit-firm rotation on the audit quality could be minimized within the initial few years of the audit engagement if companies audited by auditor specialization. This study makes a number of important contributions. Firstly, to our knowledge and it important is crystallized in examining the effect of auditor professional specialization on improving, increasing audit process quality and reducing the potential negative effects of mandatory audit-firm rotation on the audit quality.

To achieve the research main objective represented in determine the role that auditor's professional specialization to reducing the potential negative effects of mandatory audit-firm rotation on the audit quality.

The following sub objectives must be achieved:

1. Identify the relation between the auditor's professional specialization and the audit client's choices.

2. Determine the negative effects of mandatory audit-firm mandatory audit-firm rotation on the audit quality.

3. Identifying auditor's professional specialization role in reducing the potential negative effects of mandatory audit-firm rotation on the audit quality.

Thus, the problem of this study can be identified by the following questions:

1. Is there any relationship between mandatory audit-firm rotation and the audit quality?

*Corresponding author: Dr. Mohamed A Elshawarby, Assistant Professor Department of Accounting, Higher Institute for Computers and Management Information Systems, Cairo, Egypt, Tel: +20663334491; E-mail: Ishwrby@yahoo.com

Received August 01, 2017; Accepted August 24, 2017; Published August 31, 2017

Citation: Elshawarby MA (2017) Auditor's Professional Specialization Role in Reducing the Potential Negative Effects of Mandatory Audit-Firm Rotation on Audit Quality. J Account Mark 6: 252. doi: 10.4172/2168-9601.1000252

Copyright: (C) 2017 Elshawarby MA. This is an open-access article distributed under the terms of the Creative Commons Attribution License, which permits unrestricted use, distribution, and reproduction in any medium, provided the original author and source are credited. 
2. Is there any statistical significant effect of audit specialization on the relationship between mandatory audit-firm rotation and audit quality?

3. Does the professional specialization of the external auditor contribute to reducing the potential negative effects of mandatory audit-firm rotation on the audit quality?

The hypothesis of this research can be expressed as follows:

H1: There are no statistically significant differences among the categories of inquisitors about the impact of the auditor's professional specialization on the audit client's choices when audit partner plying a mandatory audit-firm rotation policy.

$\mathrm{H} 2$ : There is a significant association between auditor professional specialization and mandatory audit-firm rotation.

H3: There is a significant association between auditor professional specialization and reducing the potential negative effects of mandatory audit-firm rotation.

\section{Review of Literature}

The previous studies have been divided into three categories. These categories represented the effect of professional specialization and the audit quality, the effect of MAFR on audit process quality and presented the relationship between the auditor's professional specialization and MARF in Tables 1-3, respectively.
From the three categories of researches one can conclude that:

1. The previous studies agreed on the positive impact of the auditor's professional specialization on audit quality without clarifying the relationship between the auditor's professional specialization and the auditor's rotation and the impact on audit quality;

2. The previous studies differed on the quality of the relationship between MAFR and audit quality, including what is supportive and what is opposed, without addressing the effect of the auditor's professional specialization on this relationship;

3. Did not clarify previous studies the important mechanisms that auditor's professional specialization to reduce the potential negative effects of mandatory audit-firm rotation on audit quality.

\section{Theories}

\section{The potential negative effects of mandatory audit-firm rotation on the audit quality}

Given DE Angelo's [19] definition of audit quality had concluded that the auditor ability to detect a material misstatement in the financial statement and report the misstatement, it is expected that MAFR and auditor's specialization are relate to audit quality.

The main purpose of MAFR is to enhancing audit quality by

\begin{tabular}{|l|l|l|l|}
\hline No. & Author & Year & Study main results \\
\hline 0 & Hegazy et al. [5] & 5102 & $\begin{array}{l}\text { The results provide empirical evidence consistent with the hypothesis that auditor with professional specialization improves audit } \\
\text { quality. }\end{array}$ \\
\hline 5 & Mayangsari [6] & 5112 & $\begin{array}{l}\text { The auditor's professional specialization give significant influence on the reliability of the company's audited financial } \\
\text { statements allegedly as a result of high-quality audits }\end{array}$ \\
\hline 2 & $\begin{array}{l}\text { MINUTTI MEZA } \\
\text { MI [7] }\end{array}$ & 5102 & $\begin{array}{l}\text { The main analyses, using accrual quality as a measure of audit quality, show that firms audited by specialists have relatively higher } \\
\text { audit quality. }\end{array}$ \\
\hline 4 & Lin et al. [8] & 5100 & $\begin{array}{l}\text { Showed that assigning an auditor professional specialization in a particular client professional, will positively benefit the client } \\
\text { because they can keep the quality of company earning better, which at last will increase the audit quality. }\end{array}$ \\
\hline 5 & $\begin{array}{l}\text { Sarwoko and } \\
\text { Agoes [9] }\end{array}$ & 2010 & $\begin{array}{l}\text { The significant influence of auditor's professional specialization on audit procedures to detect fraud in a financial audit and } \\
\text { towards audit quality reflects that the auditor has a deep understanding and long experiences on the clients' specific professional. }\end{array}$ \\
\hline
\end{tabular}

Table 1: First category presented the effect of professional specialization and the audit quality.

\begin{tabular}{|l|l|l|l|}
\hline No. & Author & Year & Study main results \\
\hline 0 & Chen et al. [10] & 5112 & There is statistical evidence that the mandatory audit firm rotation has a negative effect on audit quality. \\
\hline 5 & Gul et al. [11] & 5112 & There is statistical evidence that the mandatory audit firm rotation has a negative effect on audit quality. \\
\hline 2 & Mostafa and Hussien [12] & 5101 & $\begin{array}{l}\text { The results indicate that the mostly accepted solution by the auditors to overcome the lack of independence problem is the } \\
\text { mandatory firm rotation consequently. }\end{array}$ \\
\hline 4 & Rice and Weber [13] & 5100 & There is statistical evidence that the mandatory audit firm rotation has a negative effect on audit quality. \\
\hline 2 & Siregar et al. [14] & 5105 & The results do not support that mandatory auditor rotation increases audit quality \\
\hline
\end{tabular}

Table 2: Second category presented the effect of MAFR on audit process quality.

\begin{tabular}{|l|l|l|l|}
\hline No. & Author & Year & Study main results \\
\hline 0 & Scott [15] & 5102 & $\begin{array}{l}\text { This study provides further evidence of how companies perceive the importance of having the financial statements audited by a } \\
\text { professional specialist in order to signal quality financial reporting to the market. }\end{array}$ \\
\hline 5 & $\begin{array}{l}\text { Bhoor and Khamees } \\
\text { [16] }\end{array}$ & 5102 & $\begin{array}{l}\text { Auditor professional specialization has a significant effect on audit report lag, therefore, the Jordanian companies are recommended } \\
\text { to hire professional-specialized auditors to reduce audit Report lag. }\end{array}$ \\
\hline 2 & Lim and Tan [1] & 5101 & $\begin{array}{l}\text { Main analyses, using accrual quality as a measure of audit quality, show that firms audited by specialists (vs. non specialists) have } \\
\text { relatively higher audit quality with extended. }\end{array}$ \\
\hline 4 & Randal et al. [17] & 5102 & $\begin{array}{l}\text { In particular, mediation analysis suggests that the consequences of policies that encourage Florida municipalities to consider } \\
\text { rotation impact audit quality by encouraging the use of auditors that specialize in governmental audits. }\end{array}$ \\
\hline 2 & Arthur et al. [18] & 2017 & $\begin{array}{l}\text { The results of this study show that audit partner rotation can enhance audit quality but only when both the incoming audit partner } \\
\text { and the audit firm are professional specialists. }\end{array}$ \\
\hline
\end{tabular}

Table 3: Third category presented the relationship between the auditor's professional specialization and MARF. 
stressing the audit services will be objective, by supporting the auditor's independence. The MAFR is defined as "it shall be unlawful for a registered public accounting firm to provide audit services to an issuer if the lead (or coordinating) audit partner (having primary responsibility for the audit), or the audit partner responsible for reviewing the audit, has performed audit services for that issuer in each of the X previous fiscal years of that issuer" [20]. MAFR, however, is defined as the "imposition of a limit on the period of years in which a particular registered public accounting firm may be the auditor of record for a particular issuer" [20].

The previous studies conclude that rotation would have negative $[10,11,13]$ positive $[21,22]$, or mixed or no effects $[10,23]$ on audit quality. This study concentrates on the negative effects of mandatory audit-firm rotation on the audit quality; there are several arguments against mandatory audit firm rotation:

1. The lack of experience of the new auditor in the industry to which the audit client belongs has a negative impact on audit quality.

2. There are not enough of the large audit companies to audit the large companies, which leads to a negative impact when the MAFR on the audit quality.

3. MAFR may have adverse effects on audit quality in the early years of the new audit.

4. MAFR not give the external auditor the opportunity to prepare a database about institutional knowledge of a client and its business.

5. MAFR led to weak professional skepticism and increased trusting in the entrepreneurship's estimates.

6. MAFR will lead to a loss of client-specific knowledge.

7. The auditors believe that on a cost-benefit analysis, MAFR is too costly and runs the likely risk of actually decreasing audit quality.

The relation between auditor's professional specialization and the audit client's choices when audit partner plying a mandatory audit-firm rotation policy

Although the researchers dealt with the professional specialization of the external auditor, they did not agree on a definition of professional specialization. Regarding the definition someone who works as a continuous in a particular industry and has gained the most experience in the same professional industry. For example, Solomon et al. [24] defined professional specialists as auditors who are focused on their training and gain their experience in a particular field and who spend most of their time audit clients of certain professions. Another studies defined professional specialization as $s$ a person whose share in the market increases and that he owns a share of the total market assets of a specific industry [25,26]. According to Arens et al. [27], "the professional auditor has a great knowledge about the nature of the client's business and professional affects clients' business risk and the risk of material misstatements in the financial statement.

The auditor [1] prior research results indicated that there is a positive association between the level of the auditors' professional specialization and audit quality [28]. This is probably because audit firms which are professional specialized invest time and financial resources in developing personnel and technology in specific industries, which should lead to better understanding of the clients' business, operations, and risks, and hence to improved audit quality [1].

As a result, auditors working in audit firms which are professional specialists have more opportunities to develop expertise than those working in non-specialist firms, and is also less likely to be misled by management representations [1].

Auditor professional specialization is also a proxy for the incentives for auditors to protect their reputation and minimize litigation risk [3]. Auditors who are professional specialists probably have incentives to protect their reputation because they have more to lose from poor audit quality in terms of losing future revenue streams and fee premiums. Thus, they have greater incentives than have non specialists to make high quality audits, be more independent, so as to avoid damaging this reputation [4]. In light of this, auditor professional specialization can be considered to be proxy for both expertise and the incentive to protect this expertise.

\section{The association between auditor professional specialization and reducing the potential negative effects of MARF}

There are different kinds of auditor professional specialization mechanisms available and they can be classified into five broad groupings: professional skepticism, professional independent, audit start-up costs, client-specific knowledge and professional judgment of the auditors (Figure 1). We will address the professional specialization mechanisms of the auditors as follows:

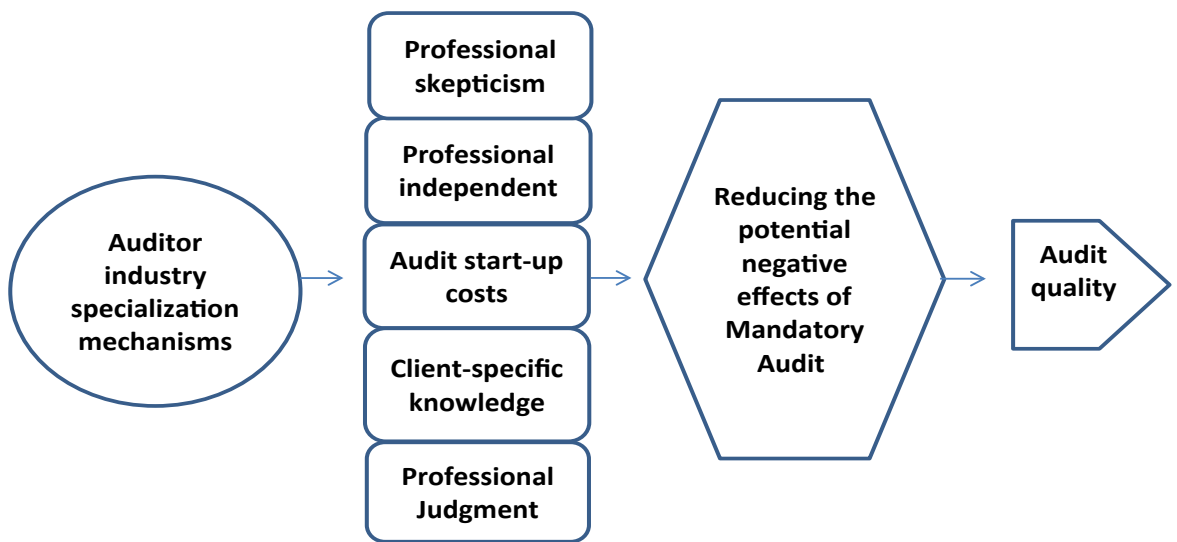

Figure 1: Conceptual model of auditor professional specialization mechanisms and their impact on reduce negative effects of mandatory audit-firm rotation. 
Auditor's professional independence: According to Arens et al. [29] definition, the independence of the external auditor is a mental attitude where it leads to objectivity and unbiased when compiling and evaluating evidence, as well as when evaluating the results and also when issuing the audit report. Auditor independence has been assessed on two criteria, that is, in fact and in-appearance. Mautz and Sharaf [30] stated that: "independence of the external auditor is a mental attitude free from the influence of others and not dependent on others and is not under the control of others. So the independence of the auditor is one of the professional specialization mechanisms and to contribute the reduction of the negative effects of the MAFR as it is not under the control of the auditing client and therefore expresses his opinion clearly and objectively in the audit report, which contributes to the improvement of audit quality

Professional skepticism: Nizarul et al. [31], the auditor's independence provides the highest quality audit contribution because in facing conflict of independence an auditor will apply professional skepticism, professional judgment and auditing standards guidelines including ethical standards fully in order to make a final decision. The professional specialization leads to increasing and improving the professional skepticism of the specialized auditor and thus positively reflects the audit quality [32]. So the professional skepticism is one of the professional specialization mechanisms of the external auditor. It supports the question and caution about the possibility of fraud in the client's financial statements, and also supports the non-acceptance of the customer's estimates and thus positively reflects the audit quality.

Personal judgment of the auditors: The personal judgment of the external auditor affects the efficiency and effectiveness of the audit process [33], and the importance of the personal judgment of the external auditor and its direct impact on increasing the efficiency of the auditor and thus improve the quality of the review, attention should be paid to the guidance, supervision and training of the references to improve the skills of good personal judgment.

Client-specific knowledge: IAS focus on the need for auditors to acquire knowledge of the nature of the industry to which the audit client belongs so that they can identify the risks in the client's environment. The increase in the auditor's ability to obtain sufficient information and experience about the nature of the industry to which the audit client belongs; increase in his ability to disclose the risks in the audit client environment [34]. As a result, a specialist auditor who has cumulative knowledge and experience in the industry of the audit client leads to increased efficiency of the auditor's performance of the audit process and, as a result, does not improve the quality of the audit [24].

Examines the effects of industry specialization on auditors' risk assessment and audit-planning decisions and finds that industry knowledge improves audit risk assessment and influences the perceived an auditor's to identify risk in an auditing client company increases if he has an understanding of the nature of the audit client's industry . Some studies [35] argue that auditing activities by auditors tend to increase the auditor's experience and knowledge of client operations and environment, increasing the ability to detect errors in financial statements. Therefore, the provision of non-audit activities to the client leading to a positive effect on audit quality.

Audit start-up costs: The study of Lowensohn et al. [36] shows that the professional specialization of the external auditor does not lead to increased costs, such as the implementation of the MAFR policy of the when the client choose non-specialist auditor leads to increased costs but the auditor's professional specialization lead to decreased the cost for:
1. Save the time it takes to collect information and gain experience in the nature of the client's business.

2. Save the time taken by the auditor in an interview with both local and international management.

3. Save the Time taken to understanding the nature of the client's business.

4. Providing marketing costs and internal and external travel costs.

All of the above shows that the professional specialization of the external auditor leads to lower initial costs while improving audit quality.

\section{Empirical Study}

\section{Research hypotheses}

To achieve the objective of the study and in light of the results of previous studies and the previous theoretical study, and the environment of the Egyptian audit, the hypotheses of this research will be formulated.

H1: There are no statistically significant differences among the categories of inquisitors about the impact of the auditor's professional specialization on the audit client's choices when audit partner plying a mandatory audit-firm rotation policy.

$\mathrm{H} 2$ : There is a significant association between auditor professional specialization and mandatory audit-firm rotation.

H3: There is a significant association between auditor professional specialization and reducing the potential negative effects of mandatory audit-firm rotation

\section{Sample of study}

Population and sample: The study community consists of external auditors practicing the profession in Egypt, and accounting professors in the Egyptian universities. One hundred and sixteen questionnaires were distributed. 107 questionnaires were filled out by the respondents and returned to us. The response rate is $92.2 \%$

Data collection: The questionnaire is divided into four sections. The first part deals with the relationship between the MAFR and the audit quality. The second part is the relation between the professional specialization of the external auditor and the audit quality. The third section deals with the negative effects of the MAFR on the quality of the review. The fourth section deals with the role of professional specialization of the external auditor to reduce these negative effects. The questions in questionnaire are measured using a 5 point Likert scale, where 1 refers to "strongly agree", 2 refers to "agree", 3 refers to "indifferent", 4 refers to "disagree", and 5 refers to "strongly disagree".

\section{Reliability of study}

In order to prove the reliability of the questionnaire list. It was distributed to a number of practicing auditors of the profession in Egypt and a number of accounting professors in the faculties of commerce in the Egyptian universities in addition to their distribution to a number of statistician copies of the questionnaire. All their notes and comments were taken into consideration before we finalized the questionnaire.

Internal consistency of the reliability of the questionnaire: By using Cronbach's coefficient alpha statistical test to measure the 
internal consistency of the questionnaire's reliability the results in Table 4 demonstrate that all indices obtained were considered to be high (above 0.70). A sample scale that shows an alpha value above 0.70 is considered as reliable, but the reliability of the questionnaire is generally considered sufficient for this research

Reliability and validity: The reliability of this survey was calculated via Cronbach's Alpha coefficients, which when applying for the research question the result shown in Table 5.

\section{Statistical testing hypotheses}

Frequency distribution relative importance and Likert attitude: The questionnaires were developed based on the Likert-scale method (Likert scaling is the most frequently applied attitude scaling technique in educational research) so that the responses can be analyzed statistically. In developing the questionnaires respondents are expected to answer the questions based on their knowledge as strongly agree $(\mathrm{SA})$, agree $(\mathrm{A})$, neutral $(\mathrm{N})$, disagree (DA) and strongly disagree (SDA). A response of strongly agree takes 5 points, agree takes 4 points, neutral takes 3 points, disagree takes 2 points and strongly disagree takes 1 point.

The questionnaires were tested for both validity and reliability. Validity is that quality of a data-gathering instrument or procedure that enables it to measure what is supposed to measure. As mentioned in section 3.5 (data type, sources and instruments) the questionnaires were adopted from published articles and thesis. Before distributing the questionnaires they were given to selected individuals who are working in the audit professional to have their comments on the questions. Reliability is the degree of consistency that the instrument or procedure demonstrates. Reliability of the responses was checked before proceeding for data analysis.
Test the validity of the first hypothesis in the study: Test the hypothesis of the result of the research question the researcher used the method of frequency distribution to determine the relative weights of the responses of the research sample on the field expressions in the survey by estimating the approval rate of the respondents whose answers were "OK" and "OK". Table 6 shows the frequency distribution of investigators' opinions on the relationship between auditor professional specialization and the potential negative effects of mandatory audit-firm rotation on the audit quality as a percentage. The examination of the results of the table shows that "mandatory audit-firm rotation when selecting professional-specialized auditor professional performance is increased to achieve audit objectives". Another statements at rates were drab (66.3\% and 63.3\%), respectively.

By examining Table 7, we note that (professional specialization contributes to the compliance of the auditors with the requirements of professional auditing rules and professional specialization encourages audit firms to apply the concept of quality within the audit offices, which has the greatest impact on the audit quality) It has achieved close ratio $(51.1 \%, 52.0 \%)$.

\section{As shown in Table 8:}

a) Factors that have obtained high percentages: The statement numbers are 9, 4, 8 and 5, that have obtained high total agree as percentages are $98 \%, 93.9 \%, 88 \%$ and $83.7 \%$.

b) Factors with moderate responses: The statement numbers are $1,6,3,7$ and 2, that have obtained moderate total agree as percentages are $98 \%, 93.9 \%, 88 \%, 83.7 \%$ and $65.3 \%$

c) Factors with moderate responses: The statements number is 10 , that have obtained moderate total agree as percentage is $53 \%$.

\begin{tabular}{|c|c|c|c|c|}
\hline $\begin{array}{c}\text { Questionnaires were } \\
\text { distributed }\end{array}$ & $\begin{array}{c}\text { Questionnaires were } \\
\text { filled }\end{array}$ & $\begin{array}{c}\text { Questionnaires were } \\
\text { right }\end{array}$ & $\begin{array}{c}\text { Percentage of questionnaires } \\
\text { received to distributed }\end{array}$ & $\begin{array}{c}\text { Percentage of correct questionnaires } \\
\text { to distributed }\end{array}$ \\
\hline 116 & 107 & 98 & 92.24 \\
\hline
\end{tabular}

Table 4: Sample of the study and questionnaire were received.

\begin{tabular}{|c|c|c|c|c|c|}
\hline S. No. & Elements of the questionnaire & Question & Statement & Cronbach's alpha coefficient & $\begin{array}{l}\text { Validity } \\
\text { coefficient }\end{array}$ \\
\hline 1 & $\begin{array}{l}\text { The relation between mandatory audit-firm rotation and auditor's professional } \\
\text { specialization }\end{array}$ & $1-3$ & 3 & 0.775 & 88.02 \\
\hline 2 & The relation between auditor's professional specialization and audit quality & $4-6$ & 4 & 0.761 & 87.24 \\
\hline 3 & Negative Effects of mandatory audit-firm rotation on the audit quality & $7-16$ & 10 & 0.804 & 89.67 \\
\hline 4 & Professional independence as one of the professional specialization mechanisms & $17-25$ & 9 & 0.706 & 84.44 \\
\hline 5 & Professional skepticism as one of the professional mechanisms. & $26-32$ & 7 & 0.713 & 84.44 \\
\hline 6 & Client-specific knowledge as one of the professional mechanisms. & $41-38$ & 6 & 0.857 & 92.57 \\
\hline 7 & Personal judgment as one of the professional mechanisms. & $42-39$ & 3 & 0.621 & 78.80 \\
\hline \multirow[t]{2}{*}{8} & Audit start-up costs as one of the professional mechanisms. & $45-43$ & 4 & 0.812 & 90.10 \\
\hline & Total & & 46 & 0.864 & 92.95 \\
\hline
\end{tabular}

Table 5: The result of research questionnaire.

\begin{tabular}{|c|c|c|c|c|c|c|c|}
\hline S. No. & Statement & $\begin{array}{l}\text { Strongly } \\
\text { agree }\end{array}$ & Agree & Natural & Disagree & $\begin{array}{l}\text { Strongly } \\
\text { disagree }\end{array}$ & $\begin{array}{l}\text { Total } \\
\text { agree }\end{array}$ \\
\hline 1 & $\begin{array}{l}\text { Auditor rotation increases audit effort and decreases } \\
\text { audit failure when choosing the professional- specialized auditor. }\end{array}$ & 215 & 2710 & 5212 & 0115 & - & 22121 \\
\hline 2 & $\begin{array}{l}\text { Mandatory audit-firm rotation when choosing a } \\
\text { professional auditor increases the accuracy of the risk } \\
\text { assessment and the planning of the audit process. }\end{array}$ & 215 & 2210 & 2112 & 210 & - & 22121 \\
\hline 3 & $\begin{array}{l}\text { Mandatory audit-firm rotation when selecting } \\
\text { professional-specialized auditor professional performance is } \\
\text { increased to achieve audit objectives } 1\end{array}$ & 22 & 22 & 4 & - & - & 24111 \\
\hline
\end{tabular}

Table 6: The frequency distribution of the relationship between the MARF- the company and the auditors of the professional (in percentage). 
Citation: Elshawarby MA (2017) Auditor's Professional Specialization Role in Reducing the Potential Negative Effects of Mandatory Audit-Firm Rotation on Audit Quality. J Account Mark 6: 252. doi: 10.4172/2168-9601.1000252

Page 6 of 9

\begin{tabular}{|c|c|c|c|c|c|}
\hline S. No. & Statement & $\begin{array}{c}\text { Strongly } \\
\text { agree }\end{array}$ & Agree & Natural & Disagree \\
\hline 1 & $\begin{array}{c}\text { Strongly } \\
\text { disagree } \\
\text { agree }\end{array}$ & 215 & 4512 & 4512 & 210 \\
\hline 2 & $\begin{array}{c}\text { Professional specialization contributes to the compliance of the } \\
\text { concept of quality within the audit offices, which has the greatest impact on } \\
\text { the audit quality. }\end{array}$ & 0015 & 4112 & 4212 & 410 \\
\hline 3 & $\begin{array}{c}\text { Professional specialization contributes to increasing the auditor's } \\
\text { ability to select clients carefully. }\end{array}$ & 20101 & 25111 \\
\hline
\end{tabular}

Table 7: The frequency distribution of the relation between auditor's professional specialization and the audit quality (in percentage).

\begin{tabular}{|c|c|c|c|c|c|c|c|}
\hline S. No. & Statement & $\begin{array}{l}\text { Strongly } \\
\text { agree }\end{array}$ & Agree & Natural & Disagree & $\begin{array}{l}\text { Strongly } \\
\text { disagree }\end{array}$ & $\begin{array}{l}\text { Total } \\
\text { agree }\end{array}$ \\
\hline 1 & $\begin{array}{l}\text { Mandatory audit firm will decrease the ability to detect } \\
\text { misstatement in the financial statements. }\end{array}$ & 5114 & 2710 & 5514 & - & - & 77121 \\
\hline 2 & $\begin{array}{l}\text { MARF weakness of the professional skepticism of the non- } \\
\text { specialized external auditor }\end{array}$ & 215 & 2210 & 2012 & 511 & 011 & 22121 \\
\hline 3 & Lack of client-specific knowledge & 410 & 5212 & 2011 & 5014 & 410 & 74121 \\
\hline 4 & Increases the audit start-up costs. & - & 4412 & 4211 & 210 & - & 22121 \\
\hline 5 & Weakness of the personal judgment of the external auditor & - & 0214 & 2412 & 0212 & - & 22171 \\
\hline 6 & $\begin{array}{l}\text { Mandatory audit firm will change the professional auditor by } \\
\text { non-specialized auditor. }\end{array}$ & - & 5212 & 2111 & 5212 & - & 72121 \\
\hline 7 & $\begin{array}{l}\text { Mandatory audit firm rotation would diminish audit quality, } \\
\text { make financial reporting less reliable. }\end{array}$ & - & 5014 & 4212 & 2012 & - & 22121 \\
\hline 8 & $\begin{array}{l}\text { Mandatory audit firm the lead to negative impact on the } \\
\text { opinion of the non-specialized auditor. }\end{array}$ & 011 & 4212 & 4512 & 0115 & 011 & 22121 \\
\hline 9 & $\begin{array}{l}\text { There is a close relationship between the client the non-specialized } \\
\text { auditor. }\end{array}$ & - & 2410 & 4212 & 511 & - & 22111 \\
\hline 10 & $\begin{array}{l}\text { Mandatory audit firm lead to lack of economic incentive for the } \\
\text { external auditor. }\end{array}$ & 210 & 0015 & 4012 & 4212 & 210 & 22111 \\
\hline
\end{tabular}

Table 8: The frequency distribution of the potential negative effects of mandatory audit-firm rotation on the audit quality when choose professional specialist auditor.

\begin{tabular}{|c|c|c|c|c|c|c|c|}
\hline $\begin{array}{l}\text { S. } \\
\text { No. }\end{array}$ & Statement & $\begin{array}{l}\text { Strongly } \\
\text { agree }\end{array}$ & Agree & Natural & Disagree & $\begin{array}{l}\text { Strongly } \\
\text { disagree }\end{array}$ & $\begin{array}{l}\text { Total } \\
\text { agree }\end{array}$ \\
\hline 1 & $\begin{array}{l}\text { Auditor's professional specialization supports the use of modern methods in the audit } \\
\text { process. }\end{array}$ & 0515 & 2712 & 4212 & 210 & - & 22111 \\
\hline 2 & Auditor's professional specialization reduces the startup cost of audit process. & 4212 & 4012 & 0212 & 011 & - & 22171 \\
\hline 3 & $\begin{array}{l}\text { Auditor's professional specialization would improve audit quality, make financial reporting } \\
\text { more reliable }\end{array}$ & 2212 & 2210 & 215 & - & - & 20121 \\
\hline 4 & Auditor's professional specialization support of the personal judgment of the external auditor. & 0214 & 2710 & 5212 & - & - & 72121 \\
\hline 5 & Auditor's professional specialization contributes to increase the client-specific knowledge 1 & 0115 & 2417 & 2410 & 011 & - & 44121 \\
\hline 6 & $\begin{array}{l}\text { Auditor's professional specialization leads to positive impact on the opinion of the non - } \\
\text { specialized auditor. }\end{array}$ & 5014 & 4412 & 2217 & - & - & 22121 \\
\hline 7 & $\begin{array}{l}\text { Auditor's professional specialization support of the professional skepticism of the non- } \\
\text { specialized external auditor. }\end{array}$ & 2214 & 5212 & 511 & - & - & 22111 \\
\hline 8 & $\begin{array}{l}\text { Auditor's professional specialization supports the professional independent of the } \\
\text { external auditor. }\end{array}$ & 4211 & 4512 & 215 & - & - & 20121 \\
\hline
\end{tabular}

Table 9: The frequency distribution of the relation between auditor's professional specialization and potential negative effects of mandatory audit- firm rotation.

From Table 9 at significance level 0.05 we can reject the null hypothesis "there are no statistically significant differences among the categories of inquisitors about the impact of the auditor's professional specialization on the audit client's choices when audit partner plying a mandatory audit-firm rotation policy" in favor of the alternative hypothesis". There are statistically significant differences among the categories of inquisitors about the impact of the auditor's professional specialization on the audit client's choices when audit partner plying a mandatory audit-firm rotation policy".

Results of correlation analysis and estimation of the relative contribution of the study variables that affect the negative effects of the MARF on the audit quality

Test the validity of the second hypothesis in the study: The researcher used correlation analysis and estimation of the relative contribution to determine the strength of the correlation between the independent variables affecting the negative impact of the external auditor on the audit quality. It is known that the correlation analysis and the estimation of the relative contribution exclude the effect of personal bias in the answers of the excluded. Variables did not obtain high frequency distribution ratios. Hence, we can rely on the results of the estimation of the correlation coefficient and the relative contribution with a high confidence level. The researcher used this method in the sections of the questionnaire to measure its effect in reducing the negative effects of MARF. The results of this method are explained below. The results of Table 10 showed that there are five negative effects on a high degree of importance that are highly correlated and have a high relative contribution and lead to a decrease in the audit quality and are in order of importance.

The results show that there are five negative effects that have a high 


\begin{tabular}{|c|c|c|c|c|}
\hline S.No. & Statement & $\begin{array}{l}\text { Correlation coefficient } \\
\text { (R) }\end{array}$ & $\begin{array}{l}\text { Relative contribution } \\
\qquad\left(\mathbf{R}^{2}\right)\end{array}$ & Morality \\
\hline 1 & $\begin{array}{l}\text { Mandatory audit firm will decrease the ability to detect misstatement in the financial } \\
\text { statements. }\end{array}$ & 11242 & 21104 & 11111 \\
\hline 2 & MARF weakness of the professional skepticism of the non-specialized external auditor. & 11224 & 21122 & 11111 \\
\hline 3 & Lack of client-specific knowledge. & 11252 & 22122 & 11111 \\
\hline 4 & Increases the audit start-up costs. & 11741 & 24172 & 11111 \\
\hline 5 & Weakness of the personal judgment of the external auditor. & 11422 & 51125 & 11111 \\
\hline 6 & Mandatory audit firm will change the professional auditor by non-specialized auditor. & 11222 & 20125 & 11111 \\
\hline 7 & $\begin{array}{l}\text { Mandatory audit firm rotation would diminish audit quality, make financial reporting less } \\
\text { reliable. }\end{array}$ & 11221 & 47120 & 11111 \\
\hline 8 & $\begin{array}{l}\text { Mandatory audit firm the lead to negative impact on the opinion of the non-specialized } \\
\text { auditor. }\end{array}$ & 11274 & 42142 & 11111 \\
\hline 9 & There is a close relationship between the client the non-specialized auditor. & 11201 & 27150 & 11111 \\
\hline 10 & Mandatory audit firm lead to lack of economic incentive for the external auditor. & 11421 & 02142 & 11111 \\
\hline
\end{tabular}

Table 10: Results of correlation analysis and estimation of the relative contribution negative effects of mandatory audit-firm rotation on the audit quality.

\begin{tabular}{|c|c|c|c|c|}
\hline S. No. & Study variables & Correlation coefficient (R) & Relative contribution $\left(\mathbf{R}^{2}\right)$ & Morality \\
\hline 1 & Client-specific knowledge & 0.720 & 51.84 & 0.000 \\
\hline 2 & Audit start-up costs & 0.837 & 70.06 & 0.000 \\
\hline 3 & Professional independence & 0.670 & 44.89 & 0.000 \\
\hline 4 & Personal judgment of the auditors and professional skepticism & 0.025 & 0.06 & 0.000 \\
\hline
\end{tabular}

Table 11: Results of the correlation analysis and estimation of the relative contribution of the proposed framework of the professional specialization mechanisms to reduce the negative impact of mandatory audit-firm rotation on the audit quality.

\begin{tabular}{|l|l|c|c|}
\hline S. No. & Elements of the questionnaire & Gradient coefficient & Standard error \\
\hline 1 & Professional skepticism & 0.088 & 0.012 \\
\hline 2 & Client-specific knowledge & 0.193 & 0.000 \\
\hline 3 & Professional independence & 0.092 & 0.000 \\
\hline 4 & Audit start-up costs & 0.148 & 0.013 \\
\hline 5 & Personal judgment of the auditors & 0.019 & 0.098 \\
\hline 6 & Use of modern methods in the increase of the audit process & 0.000 & 0.103 \\
\hline
\end{tabular}

Table 12: Results of the stepwise regression analysis to determine the most important professional specialization mechanisms that contribute to reducing the negative effects.

correlation and have a high relative contribution and reach the low quality of the review that the statements number $(4,7,8,3$ and 9) that have correlation analysis and estimation of the relative contribution are $(0.740,54.76),(0.690,47.61),(0.674,45.43),(0.629,39.56),(0.610$, $37.21)$.

The results of Table 11 confirmed the importance of the startup costs. The correlation coefficient values were 0.837 and the relative audit-firm rotation value on the audit quality was $70.06 \%$, which represents the highest effect on the study variables. While the clientspecific knowledge and professional independence came in the second order of importance with correlation coefficient $(0.720$ and 0.670$)$ with a relative contribution ( $51.84 \%$ and $44.89 \%)$, respectively.

The researcher believes that the variables that resulted from the correlation analysis and the previous relative contribution should be put into practice; otherwise they will have limited impact and therefore do not reduce the negative effect of audit quality.

From the results of the correlation analysis and the estimation of the previous relative contribution we can reject the null hypothesis "there is no a significant association between auditor professional specialization and mandatory audit-firm rotation." in favor of the alternative hypothesis "there is a significant association between auditor professional specialization and mandatory audit-firm rotation”.
Results of the stepwise regression analysis to determine a predictive model of the most important factors affecting reducing the potential negative effects of mandatory auditfirm rotation

Test the validity of the third hypothesis in the study: The researcher used the method of stepwise regression analysis in order to identify the most important predictive variables affecting the reduction of the potential negative effects of mandatory audit-firm rotation. This method is based on selecting the variables that have no self-correlation or double. Therefore, the variables that appear in the model are independent variables, and can be expected to predict a high moral level.

In examining the results of the Table 12 , it is noted that the regression analysis has selected the most important independent variables that have no self-correlation to construct the predictive model:

The correlation coefficient for these variables $(0.945)$ and the relative contribution (0.893) in the sense that the interest in these variables and work to improve their efficiency contribute to reducing the negative impact of mandatory audit-firm rotation by $89.3 \%$. Due to the high relative contribution of these variables in the results of the correlation analysis where the agreement of the results of the correlation analysis with the regression in the determination of the independent variables 
on which the predictive model is based. In regression analysis, the regression coefficient was associated with high correlation coefficient, which confirms the validity of the model as observed from the results of Tables 9-12. The results of the regression analysis indicate that the value of the coefficient of determination $\left(\mathrm{R}^{2}=0.893\right)$ was approximated with the value of the modified limiting factor $\left(\mathrm{R}^{2}=0.886\right)$ which confirms the accuracy of the model and the independence of the influencing variables.

From the results of the correlation analysis and the estimation of the previous relative contribution we can reject the null hypothesis, "there is no a significant association between auditor professional specialization and reducing the potential negative effects of mandatory audit-firm rotation" in favor of the alternative hypothesis "there is a significant association between auditor professional specialization and reducing the potential negative effects of mandatory audit-firm rotation".

\section{Conclusions}

The main objective of this research is to investigate the effect of auditor's professional specialization role in reducing the potential negative effects of MARF on the audit quality. The professional specialization of the external auditor is one of the main pillars of the financial statements quality and the audit quality. The empirical study gives evidence that MAFR can support audit quality but only when the incoming auditor is professional specialist, The capability of auditor in such a specific professional field of client will enable him to effectively select and implement audit procedures to detect material fraud that are precise and tailor made with the client condition resulting a higher quality audit. The auditor's professional specialization has a significance effect of the potential negative effects of MARF on the audit quality.

Professional skepticism, client-specific knowledge, professional independence and audit start-up costs are the most important professional specialization mechanisms that contribute to reducing the negative effects.

The present study contributes to the professional specialization literature by providing evidence that professional specialization is positively related to audit quality. Also, it provides significant evidence to support the effect of professional specialization on reducing the potential negative effects of MARF on the audit quality. The findings logically and statistically supported $\mathrm{H} 1, \mathrm{H} 2$ and $\mathrm{H} 3$. Although this study focused on the professional specialization inside the audit. Future research could may provide additional insights and support the current findings that will contribute in generalizing the results.

\section{References}

1. Lim C, Tan H (2010) Does auditor tenure improve audit quality? Moderating effects of professional specialization and fee dependence. Contemporary Accounting Research 27: 924-957.

2. Ball $R$, Shivakumar $L$ (2005) Earnings quality in UK private firms: comparative loss recognition timeliness. Journal of Accounting and Economics 39: 83-128.

3. Krishnan K, Raghunandan K, Yang JS (2007) Were former Andersen clients treated more leniently than other clients? Evidence from going-concern modified audit opinions. Accounting Horizons 21: 423-435.

4. Shu S (2000) Auditor resignations, clientele effects and legal liability. Journal of Accounting and Economics 29: 173-205

5. Hegazy M, Al Sabagh A, Handy R (2015). The effect of audit firm specialization on earnings management and quality of audit work. Journal of Accounting and Finance 15: 143-164

6. Mayangsari S (2003) An analytical review of the influence of auditor's independence on audit quality and the corporate governance mechanism. National Accounting Symposium VI, Surabaya

7. MINUTTI-MEZA MI (2013) Does auditor industry specialization improve audit quality? Journal of Accounting Research 51:779-817.

8. Lin JW, Mark IH (2010) Audit quality, corporate governance, and earnings management: A meta- analysis. International Journal of Auditing 14: 55-77.

9. Sarwoko I, Agoes S (2014) An empirical analysis of auditor's industry specialization, auditor's independence and audit procedures on audit quality: evidence from Indonesia. Procedia-Social and Behavioral Sciences164: 271-281.

10. Chen CY, Lin CJ, Lin YC (2008) Audit partner tenure, audit firm tenure, and discretionary accruals: Does long auditor tenure impair earnings quality? Contemporary Accounting Research 25: 415-445.

11. Gul FA, Fung SY, Jaggi B (2009) Earnings quality: Some evidence on the role of auditor tenure and auditors' professional expertise. Journal of Accounting and Economics 4: 265-287.

12. Mostafa D, Hussien M (2010) The impact of auditor rotation on audit quality: A field study from Egypt. German University in Cairo.

13. Rice SC, Weber DP (2012) How effective is internal control reporting under SOX 404 ? Determinants of the (non-) disclosure of existing material weaknesses. Journal of Accounting Research 50: 811-843.

14. Siregar SV, Amarullah F, Wibowo A, Anggraita V (2012) Audit tenure, auditor rotation, and audit quality: the case of Indonesia. Asian Journal of Business and Accounting 5: 55-74.

15. Scott (2013) Annual Report. Scott Technology Limited.

16. Bhoor AY, Khamees BA (2016) Audit report lag, audit tenure and auditor industry specialization; empirical evidence from Jordan. Jordan Journal of Business Administration 12: 2.

17. Elder RJ, Lowensohn S, Reck JL (2015) Audit firm rotation, audito specialization, and audit quality in the municipal audit context. Journal of Government \& Nonprofit Accounting 4: 73-100.

18. Arthur N, Endrawes M, Ho S (2017) Impact of partner change on audit quality: an analysis of partner and firm specialisation effects. Australian Accounting Review

19. DeAngelo LE (1981) Auditor independence,'low balling', and disclosure regulation. Journal of Accounting and Economics 3: 113-127.

20. Owhoso VE, Messier Jr WF, Lynch Jr JG (2002) Error detection by industryspecialized teams during sequential audit review. Journal of Accounting Research 40: 883-900

21. Davis LR, Soo BS, Trompeter GM (2009) Auditor tenure and the ability to meet or beat earnings forecasts. Contemporary Accounting Research 26: 517-548.

22. Kealey BT, Lee HY, Stein MT (2007) The association between audit-firm tenure and audit fees paid to successor auditors: Evidence from Arthur Andersen. Auditing: A Journal of Practice \& Theory 26: 95-116.

23. Chi W, Huang H, Liao Y, Xie H (2009) Mandatory audit partner rotation, audit quality, and market perception: Evidence from Taiwan. Contemporary Accounting Research 26: 359-391.

24. Solomon I, Shields MD, Whittington OR (1999) What do industry-specialist auditors know? Journal of Accounting Research 37: 191-208.

25. Francis JR, Reichelt K, Wang D (2005) The pricing of national and city-specific reputations for industry expertise in the US audit market. The Accounting Review 80: 113-136.

26. Cahan SF, Zhang W (2006) After Enron: Auditor conservatism and ex-Andersen clients. The Accounting Review 81: 49-82.

27. Arens AA, Best P, Shailer G, Fiedler B, Elder RJ, et al. (2007) Auditing and assurance services in Australia: an integrated approach. Pearson Education Australia.

28. Hogan CE, Jeter DC (1999) Industry specialization by auditors. Auditing: A Journal of Practice \& Theory 18: 1-7.

29. Arens AA, Elder RJ, Mark B (2012) Auditing and assurance services: an integrated approach. Boston: Prentice Hall.

30. Mautz RK, Sharaf HA (1961) The philosophy of auditing, American Accounting Association. Monograph No. 6. Sarasota, FL: American Accounting Association. 
Citation: Elshawarby MA (2017) Auditor's Professional Specialization Role in Reducing the Potential Negative Effects of Mandatory Audit-Firm Rotation on Audit Quality. J Account Mark 6: 252. doi: 10.4172/2168-9601.1000252

31. Nizarul M, Hapsari A, Purwanti (2007) An empirical analysis of auditor's competence and auditor's independence on audit quality, with an ethical code as moderating variable. Finance and Accounting 11: 13-30.

32. American Institute of Certified Public Accountants (2012) Section 100 -independence, integrity and objectivity. Code of Professional Conduct. New York.

33. Gibbins M (1983) Easing the tension between professional judgment and standards. CA. Magazine, The Canadian Institute of Chartered Accountants, pp: 42.
34. Mayhew BW, Wilkins MS (2003) Audit firm industry specialization as a differentiation strategy: Evidence from fees charged to firms going public. Auditing: A Journal of Practice \& Theory 22: 33-52.

35. Lennox CS (1999) Audit quality and auditor size: An evaluation of reputation and deep pockets hypotheses. Journal of Business Finance \& Accounting 26 : 779-805.

36. Lowensohn S, Johnson LE, Elder RJ, Davies SP (2007) Auditor specialization, perceived audit quality, and audit fees in the local government audit market Journal of Accounting and Public Policy 26: 705-732. 